Salman Shafiq ${ }^{1, *}$

\title{
Perceptions of Pakistani community towards their mental health problems: a systematic review
}

\author{
'Consultant General Adult Psychiatrist for Psycho-Oncology services at Shaukat Khanam Memorial Trust and Research Centre, Lahore, \\ Pakistan \\ *email: relaxedminddoutlook.com
}

DOI: $10.2478 / g p-2020-0001$

Received: 25 April 2019; Accepted: 5 December 2019

\begin{abstract}
Objectives: The objective of this research is to explore how Pakistani community perceive their mental health problems by systematically reviewing the scientific literature published on major databases. The findings expectedly will be useful for general public, for clinicians and for the researchers.

Methods: The methodology of this systematic literature search involved identifying and critically appraising studies that attempted to explore how Pakistani community perceives and understands its mental health problems. We carried out literature search on some major databases including PubMed, Cochrane database of systematic reviews and Google Scholar. We followed selection criteria where researchers aimed to find perceptions and understandings of Pakistani participants regarding their mental health by adopting scientific methodologies. The extraction of data was carried out after reading the selected papers and organising the findings under specific categories, in the form of a table. Data analysis was based on the information gathered from these studies. Results: The results suggest that Pakistani community exhibits negligible to little understanding regarding their psychological experiences and emotional processes as separate identifiable entities. Nonetheless, multiple parallel sociocultural concepts such as religion or faith driven practices and mythical or supernatural understandings are highlighted by this research. These are accepted and practiced in order to address mental health problems.

Conclusion: It appears that Pakistani community has limited understanding and scarce vocabulary to describe their inner psychological and emotional experiences. However, in order to address the mental health issues, the community exhibits a variety of responses and reactions that are driven from several unique social, cultural and religious factors. Whether these are general perceptions or causations or protective factors towards illness or possible treatment options, they all are approached and addressed with some unique understandings and perceptions that are specific to this community.
\end{abstract}

\section{Keywords}

Pakistani, mental health, perceptions, views, attitudes, behaviours, explanatory model, mental illness

\section{INTRODUCTION}

\section{Cultural variations}

Culture is sometimes called the personality of a society. There are many factors that collectively contribute towards the development and determination of culture in a society (Peacock et al., 1981). The perceptions, understandings, attitudes, behaviours and practices of the individuals vary across cultures (Peacock et al., 1981). For example, every family, every institution or every country may vary in their cultural norms. We regularly come across terms as Western culture, Eastern culture, American culture and so on that signify various practices, attitudes, behaviours or understandings exhibited by the members of these societies. Some cultural norms significantly vary across societies, for example, an eating delicacy in one culture may be considered a forbidden item in another, consumption of which may be a punishable offence (Squires et al. 2011). Cultural diversity exists in understanding mental health and related issues, across the world (Gopalkrishnan et al., 2018). 


\section{Understanding culture}

Knowledge can be gained about various aspects of culture exhibited or adapted by the members of a community by the application of a variety of scientific tools and measures. In each society, depending upon the group's personal identification, ethnicity can be decided by various factors for example ethnoreligious, ethno-lingual, ethno-racial, ethno-regional and ethno-national. These factors are usually overlapping, and more than one factor may determine the membership of an ethnic group (Peoples et al., 2011). Various ethnic groups then may exhibit various subcultures in a society that differ in their cultural norms and practices including their understanding of mental health and mental health related issues.

\section{Influence of culture on mental health}

Culture significantly influences the understandings, perceptions, conceptualisations, experiences and responses towards mental health and mental illness, in any society (Gaw et al., 1993). Cultural bound syndromes manifest as a unique set of physical or mental presentations of illnesses specific to individual cultures (Brown et al., 1989).

When it comes to understanding the mental health and related issues experienced by people from different cultures, crosscultural differences need to be appreciated and unique cultural characteristics and norms need to be learnt. Attempts need to be made to adjust cultural characteristics and expectations in care and treatment plans to provide the best possible support where required. Countries like USA and Britain have populations of citizens from varied backgrounds from across the world and understanding cultural background of several ethnic minorities for provision of best possible mental health care is an ongoing challenge in such countries (Cochrane et al., 1996).

\section{Approach of universal classifications to understand mental disorders}

One approach of understanding mental illness is appreciating it as the quality of an individual brain, mind or personality; an assumption that provides the underpinnings for current international classifications of diseases. These classifications assume that there is a common natural reality to all mankind that is universal and the symptoms underlying each diagnosis are also comparable universally regardless of the area or situation, for example, Diagnostic and Statistical Manual (DSM) classification by American Psychiatric Association or International classification of diseases by World Health Organisation (APA 2010) (WHO 1992). This view is currently accepted and practiced as an agreed standard across the world, but nevertheless, the recognition of cultural factors and their adjustment in addressing the mental health related issues is considered an essential component for utilising this model to different communities.

\section{Approach of Sociologists to understand mental disorders}

Sociologists on the other hand are more focused on sociological meanings attached with mental disorders. The social synthesis of knowledge, therefore, is more focused on intersubjective, collective social understanding of a society that is different from 'both the subjective inner words of individuals and the objective, universal worlds of natural objects' (Zerubavel, 1997). This approach follows the exploration of meanings to the roots of a phenomena in group practices or cultural assumptions. (Mannheim, 1936). Social practices have an impact on the synthesis of knowledge as well as behaviours and practices in which the knowledge is embedded.

\section{Some possible expectations from exploration of literature}

When it comes to the exploration of literature focused on understanding mental health and related issues in a society, it would be expected to find studies that may take a subjective or objective (or possibly mixed) approach towards exploring how a community appreciates and reacts towards its mental illnesses. On one hand, from service provision perspective, culture sensitivity and cultural appropriateness is sought by such explorations, and on the other hand, from service user's perspective, the cultural values and preferences are highlighted that the communities can expect to be incorporated in their care and treatment

\section{South Asian community and mental health}

South Asian communities are unique about their understanding of various cultural phenomena. South Asian culture is diverse and multiple languages are spoken in the Indian subcontinent, and there are multiple known subcultures that identify themselves according to a variety of ethnic factors (Pattanayak, 1990). For example, multiple studies have been conducted on the South Asian population highlighting the difference in explanatory model of mental illness (McCabe et al., 2004), attachment of stigma (Loya et al., 2010) or ascribing of supernatural causes to mental health problems by South Asian community (Penny et al., 2009). 


\section{Pakistani community and mental Health}

Pakistan is one of the South Asian countries and shares boundaries with India, Afghanistan, Iran and China. Islam is the official religion of the state. Urdu is the official national language. In addition, ethno-lingual, ethno-regional and ethnoracial diversity exists throughout the country. There are many subcultures identifiable, and based on these overlapping ethnic identities, the country is divided into four major parts (Newcomb, 1986). Some work has been done in Pakistan and other areas of the world (that have expatriate Pakistani populations) aimed to learn how the Pakistani community understands their mental illness and mental health problems. For example, the references made to the studies in the above section 'South Asian community and mental health' included Pakistani participants, which means that Pakistani community shares many cultural understandings exhibited by the South Asian communities in general. Some other studies have found some unique cultural manifestations with regards to mental health by this community, for example, the concept of 'high expressed emotions' is studied significantly in Pakistani community living within the country or abroad (Aisha et al., 2011; Bhugra et al., 2003). This highlights that even though living in a different country, at some level, the Pakistani community tends to hold the same values/attitudes as if they were in Pakistan.

\section{PURPOSE OF RESEARCH}

The purpose of this research is to carry out a systematic review of the literature to find the existing studies that aimed to gather information or synthesize knowledge about mental illness or mental health perceptions, views, attitudes or behaviours of the Pakistani community. After the initial literature review in the planning phase of the project, it was learnt that hitherto no such systematic search is available on this topic. It was felt that if this information is systematically gathered and utilised and if all findings are reviewed, then it will be helpful in several ways. It is hoped that the knowledge gained from this systematic review will help deepen the insight regarding Pakistani community's understanding about their mental health that will be useful for the members of the community in general, will inform practice of mental health professionals and will help researchers where appropriate. I aim to attempt to understand that what causation this community ascribes to mental health problems, how the community reacts towards the problems and what types of courses or treatment options the community takes in general to address their mental health related difficulties and problems. The absence of a systematic review of the studies is the knowledge gap in the current literature that this research aims to fill.

\section{METHODS}

\section{Literature search strategy}

To investigate how Pakistani community perceives their mental health problems, we carried out a systematic literature search on the research databases that are available in Pakistan including PubMed, Cochrane Systematic Reviews Database and Google Scholar. The relevant literature search was carried out between 1st January 2019 and 16th January 2019. The search terms included 'Pakistan', 'Pakistani', 'mental health', 'mental illness', 'mental health problems', 'ideas', 'views', 'understandings', 'perceptions, 'beliefs, 'culture,' 'cultural views', 'attitudes' and 'behaviours'. A combination of these terms was used to maximise the probability to identify relevant articles. For example, we combined terms like mental health or mental illness alternatively with one of the other terms described above, that is, to identify the studies that might throw light on the relationship of mental health/mental illness with ideas, or with views or with understandings or with behaviours exhibited by Pakistani community.

On Google scholar, complete phrases can be used as search terms, for example, the phrases like 'Cultural beliefs about mental health in Pakistani communities' and 'Pakistani mental health beliefs' were used to identify articles and then the search was broadened with more similar kind of phrases.

On PubMed, Boolean logic with Operator terms were used to identify the relevant papers. Words Pakistan OR Pakistani AND Mental illness OR mental health was searched with terms 'Understandings' OR 'Perceptions' OR 'Beliefs' OR 'Culture' OR 'Cultural views' OR 'Attitudes' OR 'Behaviours'.

Search strategies were refined initially from general to more specific terms, the details of which are described in separate sections below.

\section{Google scholar}

On Google scholar, the search was carried out with two separate terms that are described below. The terms produced huge amount of results, for example, the first term produced 37,600 results and second one produced 51,200 results. Google scholar unlike PubMed or Cochrane doesn't offer much tools for advanced search and filtration of results. Hence, the first few pages were visually searched (Titles read) and some relevant studies were identified, the numbers of which are mentioned in brackets below. 
Term 1 - 'Cultural beliefs about mental health in Pakistani communities' (20 studies identified)

Term 2 - 'Pakistani mental health beliefs' (3 studies identified)

The author considered to remove the search outcome of Google Scholar from the overall results or not include this database in the list of included databases because it doesn't generate results that are as organised as the other two databases and shall not be reproducible in a systematic manner. Instead, lots of vague and irrelevant results were generated that were difficult to be fully explored (51,200 results for example). However, this idea of exclusion was dismissed because research was carried out on this database as an overall process as planned initially and it would have been rather unhelpful not to include those studies that were identified and that matched the required criteria. Secondly, as per research ethics and transparency, the author considers it a better practice to inform the reader of the identified limitation and adjust it in overall findings rather removing it from overall plan for above reasons.

\section{Cochrane systematic review database}

Cochrane library provides facility to search with the help of Boolean Logic and Operator terms.

Following search strategies were used

First: Cultural beliefs, AND mental health or mental illness, AND Pakistani or Pakistan (outcome two results)

Second: Beliefs, AND mental health or mental illness, AND Pakistani or Pakistan (same two results)

Third: Understanding AND mental health or mental illness, AND Pakistani or Pakistan (9 results, 2 relevant)

Fourth: Perceptions AND mental health or mental illness, AND Pakistani or Pakistan (2 results, 1 relevant that was duplicate)

Fifth: Perceptions, mental health, Pakistani (1 result that was duplicate)

Sixth: Beliefs, mental illness, Pakistani (1 result that was duplicate)

\section{PubMed}

Following terms were searched on PubMed using the advanced search category:
1. ((Pakistan[Title] OR Pakistani[Title])) AND (Mental Health[Title] OR Mental Illness[Title])

2. ('Pakistan'[Title]) AND 'mental health'[Title]

3. (((Pakistan[Title]) OR Pakistani[Title]) AND Mental Illness[Title]) AND beliefs[Title]

4. ((Pakistan[Title]) OR Pakistani[Title]) AND Mental Illness[Title]

5. ((((Pakistan[Title/Abstract]) OR Pakistani[Title/ Abstract]) AND Mental Health[Title/Abstract]) OR Mental Illness[Title/Abstract]) AND beliefs[Title/ Abstract]

6. $\quad(((($ Pakistani[Title/Abstract] OR Pakistan[Title/ Abstract])) AND (Mental Health OR Mental Illness)) AND Cultural Beliefs) OR Understandings) OR Perceptions

PubMed search with broader terms like Pakistan or Pakistani AND Mental Health or Mental Illness generated too many results, that is, 570,434. However, it was noticed that this strategy picked all the entries that contained either of the four terms in the title or abstract of the articles. The search strategy was therefore refined to specific terms, for example, the final strategy is copied below:

7. ((Pakistan[Title/Abstract] OR Pakistani[Title/Abstract] $))$ AND ('Mental health'[Title/Abstract] OR 'mental illness'[Title/Abstract])) AND (aptitudes[Title/Abstract] OR ideas[Title/Abstract] OR beliefs[Title/Abstract] OR understanding ${ }^{\star}[$ Title/Abstract] OR perception*[Title/ Abstract])

\section{PAPER SELECTION STRATEGY}

The question of interest was that what are the perceptions and understandings of Pakistani community regarding their mental health and related problems that may include the studies exploring views, perceptions, attitudes, beliefs, behaviours, understandings or any other experience based description that a researcher might have attempted to explore in this community.

I therefore adapted the following criteria for the inclusion of studies in the review.

\section{Inclusion criteria}

1. I included the papers that followed an observational or interventional study design and offered details that how did the authors conclude their findings about the understanding of Pakistani community about their mental illness or mental health problems. Regarding the 
study design, all study designs were aimed to be included, for example, quantitative and qualitative, cross-sectional, experimental, quasi experimental, RCTs and so on

2. With regards to the participants in the study, it was decided that the participants must be Pakistani nationals whether living within the country or residing outside.

3. With regards to the studies conducted outside Pakistan, I aimed for studies that had majority of Pakistani participants or if the authors offered separate set of results for Pakistani population; nonetheless, it is impossible to conclude that how much the overall results would be representative of the Pakistani community. Hence, the number of such studies and the percentage/proportion of Pakistani participants has been mentioned in the results with relevant statistics instead of not including such studies or missing out on this useful data.

4. Studies that were conducted upon minority groups in Pakistan were included because again it is felt that although the groups are in minority, yet they tend to share the same values and attitudes as that of majority though with some cultural variations. The first two papers (in Table 1) included within the review are good references in support of this fact.

5. With regards to the sample size, we didn't fix a criterion and any number of participants was acceptable. Nonetheless, as mentioned earlier, we expected Pakistani participants to be in majority.

\section{Exclusion criteria}

1. Studies exploring heterogenous group of South Asian communities including Pakistani nationals but not offering separate set of results for Pakistani community were excluded.

2. Studies that didn't follow a research methodology were excluded, for example, some articles were available that contained scholarly discussions based on personal opinions of the authors.

3. Studies that explore understanding or perceptions on physical health problems or physical illnesses, because I have been focused on mental health specifically.

4. Studies aimed to find the efficacy of a specific intervention instead of checking perceptions, because my overall aim was not to explore the efficacy of any interventions.

5. Studies that don't specify ethno-national identities of the participants. For example, one study approached participants from ethno-religious identities alone was excluded. It's simply because I didn't know what proportion belonged to Pakistan.
6. There were some studies identified that aimed to assess the efficacy, validity or reliability of a research tool used for mental health and mental health related issues in the Pakistani community. The importance of these studies was appreciated, nonetheless they were excluded because the overall aim was to gather knowledge on general perceptions and behaviours, but not in the context of establishing importance or utility of a scientific tool. Secondly, it was felt that it would be difficult to establish the difference between results obtained from these two different kinds of sources that would have implications on the knowledge that I aimed to gather.

7. Studies not offering any details on methodology were not included, as I was unsure if the scientific methodology is used or not.

8. Studies from other languages except for English are not included. Given that the topic is culturally/nationality related, it was expected that national studies on the subject would be available on any database in Urdu language that would be quite relevant for the review. However, the researcher did not identify any such database or individual articles in Urdu language.

\section{Reasons of exclusion of individual articles and studies}

The following papers were excluded for the reasons described next to each:

I. One study was excluded because although it involved Pakistani community, but the total number of Pakistani participants was only $15 \%$, whilst the other participants were Indian nationals and had different religious denomination.

I I. Although the research terms brought up a Cochrane literature review as outcome of the search, however, it was noticed that the title of the review was 'Mental health and ethnic minorities: A review of the literature and implications for services. This did not include separate results for Pakistani community and didn't match with my primary questions under investigation; hence, it was not included.

I I I. One study was excluded because it was carried out with South Asian communities in London, UK but did not specify what percentage of participants were Pakistani in origin.

IV. Three articles were excluded because they were scholarly articles and did not involve any research methodology. They were personal opinions of the authors with some 
information in the form of statistics about several issues related to mental health in Pakistan.

V. One article discussed the issue of stigma - again as a scholarly article in the form of opinion and did not include any research methodology.

VI. One article was excluded because although it contained the words Pakistan or Pakistani in abstract, but this study was conducted in Maharashtra India and did not include Pakistani participants.

VII. One study was conducted in Scotland that mentioned involving Black and ethnic minority groups; however, it didn't specify what percentage of minorities included in the study were of Pakistani origin.

VIII. Another study again from Scotland was excluded because it covered three ethnic minorities including Pakistani, Chinese and Indians; however, the methodology used was focused group and a separate set of results for Pakistani participants was not possible.

IX. Another study from the UK was excluded because it identified participants according to their ethno-religious denominations and did not specify ethno-national identities.

X. Two studies were excluded because they were trials for specific interventions in Pakistani community, that is, randomised controlled trials of carrying out CBT in depressed and psychotic patients. The trials were aimed at checking the efficacy of interventions and not exploring the perceptions.

XI. A scholarly article discussed women's mental health in Pakistan and was excluded as it didn't involve any research methodology.

XII. Two studies were excluded as they aimed to check the impact of a specific programme or intervention in Pakistani community and didn't explore perceptions directly.

XIII. One study was excluded as it aimed to check the validity and reliability of a specific mental health questionnaire in the Pakistani population that didn't match our primary research question.

XIV. One study was excluded because it was available in German language, though the abstract was available in English language. Due to limited language abilities of author, the complete information required to be included in the review could not be retrieved.

XV. One study, which offered only the abstract, was excluded. The authors were contacted via email, who confirmed that a full text is not available at present.

\section{DATA EXTRACTION AND ASSESSMENT OF BIAS}

The extracted data contained information about the name of author, year of publication, study design, sample size and details of sample demographics, type of instrument used, name of country where study was conducted, what are the general and specific findings and what is the possible bias. Biases were assessed by Cochrane criteria (Higgins et al., 2017). The following parameters that were used to assess bias:

1. If philosophical underpinnings of the research are clarified?

2. If reasons are provided for the choice of methodology and design?

3. If credibility (Internal Validity) is justified?

4. If transferability (External validity or generalisability) is justified?

5. If dependability (Reliability or consistency) is justified?

6. Confirmability (Objectivity or neutrality) justified?

The details of individual terms and how they apply to quantitative or qualitative data are supplied in Table 2 below. The author has qualifications in the subject of Health Research and has formally learnt skills for critically analysing both quantitative and data. I went through all the articles and critically analysed them on the above criteria. In order to simplify the findings and make them presentable for common reader, I labelled them $\mathrm{N}$ = None, $\mathrm{L}=$ Little, $\mathrm{A}=$ Adequate, $\mathrm{D}=$ Detailed based on the information provided in the study in each category. According to my critical appraisal and judgment skills, the conclusion was made that under what category $(\mathrm{N}, \mathrm{L}, \mathrm{A}, \mathrm{D})$ does the sought information fall. For example, if there was no information provided at all in the paper of the philosophical underpinnings or epistemological background of the knowledge sought by the application of research tools applied, then it was labelled $\mathrm{N}$ (None); if minimal information was provided though very superficial, for example, that authors describe that they are using any specific tool for a certain aim, then it was labelled L (Little). If some discussion on epistemological underpinnings were offered and related to the overall aim of the study, it was labelled as A (Adequate); whilst a detailed description of epistemological background that offered to qualify why this particular study design was chosen and what was the critical appraisal of the choice of that design on the overall study and its results was considered as D (Detailed). 


\section{RESULTS}

\section{Outcome of literature search}

Total relevant articles identified on Google Scholar were 23, on Cochrane Database were 3 and on PubMed were 45, making a total of 71 . When it came to organise the studies under the four broader categories of Identified, Screened, Found Eligible and Included, the Prisma Flow Diagram was found helpful. Out of 71, twenty-eight records were found to be duplicated hence removed. 43 records were screened and out of these, 17 were excluded for various reasons. Number of Full-text articles that were assessed for eligibility were 26, and out of those 26 articles, 7 articles were excluded on full text review for various reasons. Finally, the number of studies that were included in the qualitative synthesis were 19, and these were included for interpretation and gathering knowledge.

They are summarised in the form of a table labelled as Table 1.

\section{General perceptions of Pakistani community towards mental health}

Overall, the combined knowledge from all studies (some indicating directly directly and others indirectly) suggest that Pakistani community living within the country seem to show negligible to little understanding of mental health problems including mental illness. Those living abroad also appear to show differences in their model of understanding compared to the countries of emigration. For example, Naeem et al. (2007) report that in their study, people had very little knowledge of mental illness in general and depression in specific. The authors report that there was a striking feature noted in the description of the participants that comprised of lack of name for the condition that they were experiencing, though description of physical symptoms was offered, and they felt that they suffered from some sort of physical illness. In the same study, researchers found that participants typically used expression like 'weakness of brain or illness of brain', 'illness of suffocation, 'illness of poor sleep' or 'tension' as the cause of their problem. When asked if they heard or knew anything about 'Depression', they answered in negative. Somatisation was also reported by Rashda et al, (2000) in the first and second-generation Pakistani community living in the United Kingdom. The researcher concluded that somatisation is a part of the model of understanding of this community. Choudhry et al. $(2013,2018)$ worked with two ethnic minority groups, one of which had a different religious identity compared to the dominant group in the country; however, the findings seem to suggest that with regards to the perceptions of mental illness, these minority groups also had more or less similar kind of views as that of the majority population, for example, one of the identified themes comprised of complete denial of the mental illness altogether. Some studies attempted to find illness perceptions about Depression and Schizophrenia in particular. Cinnirella et al. (1999) conducted their study on Pakistani community in the UK and reported that beliefs about Schizophrenia and depression were ambiguous, contradictory and subject to confirmation by personal experience rather than tested via falsification. In Pakistan, Zafar et al. (2008) focused on finding perceptions of people about Schizophrenia and reported that only $30 \%$ of participants attributed mental illness as the main cause of psychotic symptoms, whilst the majority attributed Schizophrenia to 'God's will', 'superstitious ideas', 'loneliness' or 'unemployment'.

\section{Understanding of causation of their mental illness by Pakistani community}

When we combine the knowledge from all the studies that were conducted on majority ethnic groups that throw light on causation of mental illness, four themes regarding the causation of mental illness emerged. These include mental illness as an outcome of medical or physical health problem, mental illness as an outcome of spiritual or supernatural problems, mental illness as an outcome of religious problem and mental illness as an outcome of psychological problem. Even when we incorporate the understanding of minorities living within Pakistan, Choudhry et al. $(2013,2018)$ reported that participants identify biological/medical reasons more as possible cause of mental illness, instead of psychological or psychiatric reasons.

Indirectly, the same information emerged from some studies that aimed to find the choice of practitioners that Pakistani people preferred to address their mental health problems, for example, some studies found that participants chose the General Practitioners and Hakims (those who deal with nonallopathic medications), as the findings reported by Mirza et al. (2006). Pakistani people living within Pakistan or outside as immigrants also like to consult faith healers and religious leaders for the experiences and presentations that might be indicative of mental health problems.

Supernatural and spiritual reasons are also consistently identified by the researchers as one of the major causes of mental health problems. If we think of minorities first, Choudhry et al. $(2013,2018)$ reported supernatural reasons in both papers as causative factors identified by participants for their mental health problems. Studies conducted on majority also confirm the same; for example, Saeed et al. (2000) found that the faith healers have a classification of spiritual and supernatural causes 
Table 1.

\begin{tabular}{|c|c|c|c|c|c|c|c|}
\hline Author & $\begin{array}{c}\text { Year of } \\
\text { publication }\end{array}$ & $\begin{array}{l}\text { Country of } \\
\text { study }\end{array}$ & Study design & $\begin{array}{l}\text { Sample } \\
\text { size }\end{array}$ & $\begin{array}{l}\text { Sample demographics } \\
\text { Gender: Age Method of } \\
\text { recruitment/sampling: }\end{array}$ & $\begin{array}{c}\text { Type of } \\
\text { instrument/ } \\
\text { method used }\end{array}$ & Title and findings \\
\hline $\begin{array}{l}\text { Choudhry } \\
\text { et al. }\end{array}$ & 2013 & Pakistan & Focused group & 7 & $\begin{array}{c}\text { Gender: } \\
4 \text { males } \\
3 \text { females } \\
\text { Age: } 24 \text { to } 42 \text { years } \\
\text { Method: Homogenous } \\
\text { purposive sampling }\end{array}$ & $\begin{array}{c}\text { Focused group } \\
\text { followed by } \\
\text { interpretative } \\
\text { phenomenological } \\
\text { analysis }\end{array}$ & $\begin{array}{l}\text { "Perception of mental health in Pakistani nomads: } \\
\text { an interpretative phenomenological analysis." } \\
\text { Four themes about perception of mental illness } \\
\text { are derived: } \\
\text { 1) denial of illness altogether, } \\
\text { 2) description of mental health as medical or } \\
\text { spiritual problems, } \\
\text { 3) causation of mental illness due to unfulfilled } \\
\text { needs mainly inadequate education and lack of } \\
\text { opportunity for spiritual activities, and } \\
\text { 4) psychological disturbances that emanate from } \\
\text { lack of sharing, that is, rich don't share with poor } \\
\text { and with self-downing, that is, what can we do, it's } \\
\text { all circumstantial. }\end{array}$ \\
\hline $\begin{array}{l}\text { Choudhry } \\
\text { et al. }\end{array}$ & 2018 & Pakistan & $\begin{array}{c}\text { In depth } \\
\text { interviews } \\
\text {. }\end{array}$ & 12 & $\begin{array}{c}\text { Gender: } \\
5 \text { males } \\
7 \text { females } \\
\text { Age: } \\
18 \text { to } 26 \text { years } \\
\text { Method of sampling: } \\
\text { Snowball sampling }\end{array}$ & $\begin{array}{l}\text { In depth interviews } \\
\text { Interpretative } \\
\text { phenomenological } \\
\text { analysis (IPA) }\end{array}$ & $\begin{array}{l}\text { “Mental health conceptualisation and resilience } \\
\text { factors in Kalasha youth: An indigenous ethnic and } \\
\text { religious minority community in Pakistan" } \\
\text { Three superordinate themes were identified each } \\
\text { with emergent themes. They are: } \\
\text { 1) psychological resilience/cultural protective } \\
\text { Factors bulering against mental health } \\
\text { problems (intra-communal bonding and } \\
\text { sharing; Kalasha festivals and traditions; purity } \\
\text { concept; behavioural practice of happiness and } \\
\text { cognitive patterns), } \\
\text { 2) perceived causes of mental health issues } \\
\text { (biological \& psychosocial; supernatural and } \\
\text { spiritual; environmental), and } \\
\text { 3) preferred interventions [Shamanic treatment; } \\
\text { Ta'awiz (Amulets); communal sharing and } \\
\text { problem solving; medical treatment; herbal } \\
\text { methods]. }\end{array}$ \\
\hline $\begin{array}{c}\text { Cinnirella } \\
\text { et al. }\end{array}$ & 1999 & England & $\begin{array}{l}\text { Open-ended } \\
\text { interview }\end{array}$ & 54 & $\begin{array}{l}\text { Method of sampling: } \\
\text { Gampling procedure was a } \\
\text { mix of quota, convenience } \\
\text { and snowball techniques } \\
\text { with all participants being } \\
\text { female volunteers. } \\
\text { Age: Not provided in paper }\end{array}$ & $\begin{array}{c}\text { Open ended (in } \\
\text { depth) interview } \\
\text { followed by } \\
\text { qualitative thematic } \\
\text { analysis }\end{array}$ & $\begin{array}{l}\text { "Religious and ethnic group influences on beliefs } \\
\text { about mental illness: A qualitative interview study." } \\
\text { 1) Beliefs about depression and schizophrenia } \\
\text { were seen to be ambiguous, contradictory, } \\
\text { and subject to confirmation through personal } \\
\text { experience rather than tested via falsification. } \\
\text { 2) Religious affiliation intertwines with ethnic } \\
\text { origin or results in some important differences } \\
\text { in the beliefs prevalent in different ethnic and } \\
\text { religious communities in Britain. } \\
\text { 3) In terms of religion, Muslim participants in } \\
\text { particular felt that religion did have an impact } \\
\text { on their choice of strategies for dealing with } \\
\text { depression. } \\
\text { 4) Participants indicated a fear of community } \\
\text { stigma associated with mental illness or even to } \\
\text { the act of seeking help, that impacts the actual } \\
\text { coping strategies and help-seeking behaviours. } \\
\text { 5) In terms of help-seeking behaviours, a tendency } \\
\text { for members of ethnic/religious communities } \\
\text { to prefer consultations with professionals of the } \\
\text { same ethnic background was noted. } \\
\text { 6) Fear of being misunderstood due to ignorance } \\
\text { of cultural and religious practices, intertwines } \\
\text { in a complex fashion with a fear of being the } \\
\text { target of racism. }\end{array}$ \\
\hline
\end{tabular}


Continued Table 1.

\begin{tabular}{|c|c|c|c|c|c|c|c|}
\hline Author & $\begin{array}{c}\text { Year of } \\
\text { publication }\end{array}$ & $\begin{array}{c}\text { Country of } \\
\text { study }\end{array}$ & Study design & $\begin{array}{c}\text { Sample } \\
\text { size }\end{array}$ & $\begin{array}{l}\text { Sample demographics } \\
\text { Gender: Age Method of } \\
\text { recruitment/sampling: }\end{array}$ & $\begin{array}{c}\text { Type of } \\
\text { instrument/ } \\
\text { method used }\end{array}$ & Title and findings \\
\hline Croot et al. & 2008 & UK & $\begin{array}{l}\text { In-depth } \\
\text { interviews }\end{array}$ & 16 & $\begin{array}{c}\text { Gender: } \\
4 \text { males } \\
12 \text { females } \\
\text { Method of sampling: } \\
\text { Purposive sampling } \\
\text { Age: Not provided in paper, } \\
\text { but all participants are } \\
\text { parents whilst one was a } \\
\text { grandparent }\end{array}$ & $\begin{array}{l}\text { In-depth interviews } \\
\text { followed by } \\
\text { thematic analysis } \\
\text { of data }\end{array}$ & $\begin{array}{l}\text { "Perceptions of the causes of childhood disability } \\
\text { among Pakistani families living in the UK." } \\
\text { Following perceptions and causes of childhood } \\
\text { disability among Pakistani families living in the UK } \\
\text { were identified: } \\
\text { 1) Theological reasons for disability included } \\
\text { gift from God, test from God, chosen parents, } \\
\text { punishment, curse and so on. } \\
\text { 2) There could be more than one reason for } \\
\text { disability including biomedical reasons, } \\
\text { individual responsibility or catching disability. } \\
\text { 3) There is a relationship between theological } \\
\text { and biomedical belief that results in the } \\
\text { development of stigma. }\end{array}$ \\
\hline $\begin{array}{c}\text { Gunasinghe } \\
\text { et al. }\end{array}$ & 2018 & UK & $\begin{array}{l}\text { Semi- } \\
\text { structured } \\
\text { Interview }\end{array}$ & 6 & $\begin{array}{l}\text { Gender: All females } \\
\text { Method of sampling: } \\
\text { Purposive sampling } \\
\text { Age: } 24 \text { to } 40 \text { years }\end{array}$ & $\begin{array}{c}\text { Six semi structured } \\
\text { interviews followed } \\
\text { by IPT }\end{array}$ & $\begin{array}{l}\text { “Understanding how izzat impacts the lived } \\
\text { experiences of young Muslim Pakistani women in } \\
\text { the UK: A phenomenological approach" } \\
\text { How 'Izzat' impacts the lived experience of young } \\
\text { Pakistani women living in the UK three themes are } \\
\text { identified: } \\
\text { 1) The rules of izzat need to be abided by women. } \\
\text { 2) Participants need to be negotiating tensions } \\
\text { considering izzat, to enable them to self- } \\
\text { manage or seek help. Even for those possible } \\
\text { life experiences that might lead to self-harm } \\
\text { and attempted suicide. } \\
\text { 3) Participants need to be speaking out/breaking } \\
\text { the 'rules' specially attached to izzat. The rules } \\
\text { appear to vary over the life course and are } \\
\text { influenced by migration. }\end{array}$ \\
\hline Gilbert et al. & 2004 & UK & $\begin{array}{c}\text { Focused } \\
\text { groups }\end{array}$ & Not given & $\begin{array}{l}\text { Gender: All females } \\
\text { Method of sampling: } \\
\text { Purposive sampling } \\
\text { Age: Three groups done } \\
\text { mean age in each is } 20,32 \\
\text { and } 57 \text { years old. }\end{array}$ & $\begin{array}{l}\text { Three focused } \\
\text { groups with } \\
\text { different age } \\
\text { groups, followed by } \\
\text { thematic analysis }\end{array}$ & $\begin{array}{l}\text { "A focus group exploration of the impact of izzat, } \\
\text { shame, subordination and entrapment on mental } \\
\text { health and service use in South Asian women living } \\
\text { in Derby." } \\
\text { The key themes to emerge were that } \\
\text { 1) Mental health is linked to each of the themes of } \\
\text { izzat, shame, subordination and entrapment. } \\
\text { 2) Various themes were linked to mental health; } \\
\text { such as having to meet obligations, feeling a } \\
\text { failure in roles, and lacking support. } \\
\text { 3) Some participants felt that it would be better } \\
\text { to commit suicide than to leave an abusive } \\
\text { relationship, to protect izzat. }\end{array}$ \\
\hline $\begin{array}{c}\text { Hussain } \\
\text { et al. }\end{array}$ & 2017 & Pakistan & $\begin{array}{l}\text { Questionnaire } \\
\text { based data } \\
\text { collection }\end{array}$ & 100 & $\begin{array}{c}\text { Gender: } \\
45 \text { males } \\
55 \text { females } \\
\text { Age: } 18 \text { to } 65 \text { years } \\
\text { Method of sampling: } \\
\text { Not described in paper }\end{array}$ & $\begin{array}{l}\text { Four } \\
\text { questionnaires; a } \\
\text { socio-demographic } \\
\text { questionnaire, the } \\
\text { Illness Perception } \\
\text { Questionnaire for } \\
\text { Schizophrenia } \\
\text { (IPQ-S), } \\
\text { Drug attitude } \\
\text { Inventory-10 } \\
\text { (DAl) and } \\
\text { Multidimensional } \\
\text { Scale of Perceived } \\
\text { Social Support } \\
\text { (PSS) completed by } \\
\text { all participants }\end{array}$ & $\begin{array}{l}\text { "Illness perceptions in patients of schizophrenia: A } \\
\text { preliminary investigation from Lahore, Pakistan." } \\
\text { 1) With regards causation of illness stress, family } \\
\text { problems, lack of friends \& financial worries } \\
\text { were endorsed strongly by patients as cause of } \\
\text { their mental illness. } \\
\text { 2) Ambiguity regarding their mental illness } \\
\text { duration and personal control was observed. } \\
\text { 3) Patients' perceived significant negative } \\
\text { consequences, negative emotional response, as } \\
\text { well as had poor understanding of their mental } \\
\text { illness and treatment effectiveness. }\end{array}$ \\
\hline
\end{tabular}


Continued Table 1.

\begin{tabular}{|c|c|c|c|c|c|c|c|}
\hline Author & $\begin{array}{c}\text { Year of } \\
\text { publication }\end{array}$ & $\begin{array}{c}\text { Country of } \\
\text { study }\end{array}$ & Study design & $\begin{array}{l}\text { Sample } \\
\text { size }\end{array}$ & $\begin{array}{l}\text { Sample demographics } \\
\text { Gender: Age Method of } \\
\text { recruitment/sampling: }\end{array}$ & $\begin{array}{c}\text { Type of } \\
\text { instrument/ } \\
\text { method used }\end{array}$ & Title and findings \\
\hline Imran et al. & 2015 & Pakistan & $\begin{array}{l}\text { Questionnaire } \\
\text { based data } \\
\text { collection }\end{array}$ & 52 & $\begin{array}{l}\text { Gender: } 67 \% \text { females and } \\
\quad 33 \% \text { males } \\
\text { Age: Mean age } 12.7 \text { years } \\
\text { (Range } 11 \text { to } 18 \text { years) } \\
\text { Method of sampling: Not } \\
\text { mentioned }\end{array}$ & $\begin{array}{l}\text { Interviews using } \\
\text { a structured } \\
\text { questionnaire } \\
\text { including the } \\
\text { Illness Perceptions } \\
\text { Questionnaire- } \\
\text { Revised (IPQ-R). }\end{array}$ & $\begin{array}{l}\text { "Illness perceptions in adolescents with a } \\
\text { psychiatric diagnosis in Pakistan." } \\
\text { Exploring the illness perceptions in adolescents } \\
\text { with a psychiatric diagnosis in Pakistan revealed } \\
\text { following: } \\
\text { 1) It was noticed that males had significantly } \\
\text { higher scores on timeline and emotional } \\
\text { representation, suggesting strongly held beliefs } \\
\text { about chronicity of their illness and anger and } \\
\text { worry about their condition. } \\
\text { 2) Adolescents' own emotional state, stress, } \\
\text { family problems and bad luck were endorsed } \\
\text { by participants as some of the causal factors in } \\
\text { their mental illness. }\end{array}$ \\
\hline James et al. & 2002 & $\begin{array}{l}\text { Pakistan } \\
\text { and India }\end{array}$ & $\begin{array}{l}\text { Two separate } \\
\text { interviews } \\
\text { three months } \\
\text { apart }\end{array}$ & 948 & $\begin{array}{c}\text { Cender: } \\
\text { Gerd are, } \\
\text { Female } 87.3 \% \text { standard care, } \\
71.4 \% \text { integrated care } \\
\text { Age: } 16 \text { to } 60 \text { years } \\
\text { Method of sampling: } \\
\text { Purposive random selection }\end{array}$ & $\begin{array}{l}\text { 1. A range of } \\
\text { measures were } \\
\text { administered } \\
\text { via face to face } \\
\text { study at entry } \\
\text { into the study } \\
\text { and again three } \\
\text { months later } \\
\text { 2. Symptoms of } \\
\text { depression and } \\
\text { anxiety, quality } \\
\text { of life, disability } \\
\text { and service } \\
\text { utilisation were } \\
\text { recorded. } \\
\text { 3. Individual's } \\
\text { contact with } \\
\text { primary health } \\
\text { care providers, } \\
\text { indigenous } \\
\text { practitioners } \\
\text { or healers } \\
\text { and hospital } \\
\text { services were } \\
\text { recorded, } \\
\text { 4. Personal } \\
\text { perceptions } \\
\text { of providers } \\
\text { recorded along } \\
\text { with issues } \\
\text { affecting access } \\
\text { to services } \\
\text { and attitudes } \\
\text { towards mental } \\
\text { health. }\end{array}$ & $\begin{array}{l}\text { "Demand for, access to and use of community } \\
\text { mental health care: lessons from a demonstration } \\
\text { project in India and Pakistan." } \\
\text { Following were noted: } \\
\text { 1) Individual's use of integrated mental health and } \\
\text { other care was modest. Principal (self-rated) } \\
\text { supply-side factors were the cost of care, } \\
\text { distance from treatment centre, a perception } \\
\text { that care would not be effective and concerns } \\
\text { regarding stigma. } \\
\text { 2) Perceptions improved over three months, } \\
\text { accompanied by an increased preference for } \\
\text { public over private providers. but this was not } \\
\text { restricted to the integrated care localities. } \\
\text { 3) The use land therefore, effectiveness) of mental } \\
\text { health services integrated into primary care is } \\
\text { influenced by the health-seeking behaviours } \\
\text { and perceptions of the local population. }\end{array}$ \\
\hline
\end{tabular}


Table 1.

\begin{tabular}{|c|c|c|c|c|c|c|c|}
\hline Author & $\begin{array}{c}\text { Year of } \\
\text { publication }\end{array}$ & $\begin{array}{c}\text { Country of } \\
\text { study }\end{array}$ & Study design & $\begin{array}{l}\text { Sample } \\
\text { size }\end{array}$ & $\begin{array}{l}\text { Sample demographics } \\
\text { Gender: Age Method of } \\
\text { recruitment/sampling: }\end{array}$ & $\begin{array}{l}\text { Type of } \\
\text { instrument/ } \\
\text { method used }\end{array}$ & Title and findings \\
\hline Mirza et al. & 2006 & Pakistan & $\begin{array}{l}\text { Semi- } \\
\text { structured } \\
\text { questionnaire }\end{array}$ & 157 & $\begin{array}{c}\text { Gender: } \\
\begin{array}{c}\text { Male } \mathrm{n}= \\
\text { years) }\end{array} \\
\text { (mean age } 36.56 \\
39.25 \text { years) } \\
\text { Age: Mean } 38.14 \text { years } \\
\text { (median } 35, \text { Mode } 35 \text { ) } \\
\text { Method of recruitment: } \\
\text { Purposive sampling }\end{array}$ & $\begin{array}{l}\text { 1. A semi- } \\
\text { structured } \\
\text { questionnaire } \\
\text { was devised and } \\
\text { administered. } \\
\text { 2. Later, } \\
\text { participants } \\
\text { were seen and } \\
\text { diagnosed by a } \\
\text { psychiatrist } \\
\text { to confirm } \\
\text { diagnosis of } \\
\text { mental illness. }\end{array}$ & $\begin{array}{l}\text { "Primary mental health care in rural Punjab, } \\
\text { Pakistan: Providers, and user perspectives of the } \\
\text { effectiveness of treatments." } \\
\text { Aim was to } \\
\text { a) describe the types of mental health care } \\
\text { providers in rural Punjab, Pakistan, } \\
\text { b) appreciate patients' perception of the different } \\
\text { types of treatments used, and } \\
\text { c) find out about their effectiveness. } \\
\text { Following types of health care providers were } \\
\text { identified: } \\
\text { 1) General practitioner (GP) } \\
\text { 2) Religious Healer (Maulvi, Peer, Fakir) } \\
\text { 3) Hakim (A form of Unani/Greek medicine) } \\
\text { 4) Homeopathic Doctors } \\
\text { 5) Faith healers (Amil, Sinyasi) } \\
\text { All were using a range of physical, spiritual and } \\
\text { psychotherapeutic treatments. Of these, patients } \\
\text { found GP treatments most effective. }\end{array}$ \\
\hline $\begin{array}{l}\text { Naeem } \\
\text { et al. }\end{array}$ & 2007 & Pakistan & $\begin{array}{l}\text { In depth } \\
\text { interview }\end{array}$ & 9 & $\begin{array}{c}\text { Gender: } \\
3 \text { males } \\
6 \text { females } \\
\text { Age: } 18 \text { to } 60 \text { years } \\
\text { Method of recruitment: } \\
\text { Purposive Sampling }\end{array}$ & $\begin{array}{l}\text { Interviews lasting } \\
\text { between } 30 \text { and } 60 \\
\text { minutes }\end{array}$ & $\begin{array}{l}\text { "Views of depressed patients in Pakistan } \\
\text { concerning their illness, its causes, and } \\
\text { treatments." } \\
\text { 1) The authors discovered that patients had very } \\
\text { little knowledge of mental illnesses in general, } \\
\text { and depression in particular. } \\
\text { 2) They believed that mental health problems were } \\
\text { the result of stress or trauma, and that only } \\
\text { medicines could help them. } \\
\text { 3) Patients had no knowledge of the roles of } \\
\text { psychologists or psychotherapy. } \\
\text { 4) Their model of understanding mental } \\
\text { illnesses appeared to represent a psychosocial } \\
\text { understanding, with physical symptoms being } \\
\text { their main concern. }\end{array}$ \\
\hline Saeed et al. & 2000 & Pakistan & $\begin{array}{l}\text { Screening at } \\
\text { faith healers' } \\
\text { practice, } \\
\text { followed by } \\
\text { conducting } \\
\text { GHQ-12 on all } \\
\text { attenders }\end{array}$ & 144 & $\begin{array}{c}\text { Gender: } \\
192(64 \%) \text { females and } 106 \\
(36 \%) \text { males } \\
\text { Age: Not given } \\
\text { Method of recruitment: } \\
\text { Purposive sampling }\end{array}$ & $\begin{array}{l}\text { 1. PAS interview } \\
\text { 2. The work of } \\
\text { faith healers } \\
\text { was observed } \\
\text { and recorded. } \\
\text { 3. The mental } \\
\text { status of } \\
\text { attenders } \\
\text { was assessed } \\
\text { using a two- } \\
\text { stage design: } \\
\text { screening } \\
\text { using the } \\
\text { General Health } \\
\text { Questionnaire } \\
\text { followed by } \\
\text { diagnostic } \\
\text { interview using } \\
\text { the Psychiatric } \\
\text { Assessment } \\
\text { Schedule }\end{array}$ & $\begin{array}{l}\text { "The prevalence, classification and treatment of } \\
\text { mental disorders among attenders of native faith } \\
\text { healers in rural Pakistan." } \\
\text { 1) The researchers found that the classification } \\
\text { used by faith healers is based on the mystic } \\
\text { cause of disorders: saya (27\%), jinn possession } \\
\text { (16\%) or churail (14\%). } \\
\text { 2) Sixty one percent of attenders were given a } \\
\text { research diagnosis of mental disorder: major } \\
\text { depressive episode (24\%), generalized anxiety } \\
\text { disorder (15\%) or epilepsy (9\%). } \\
\text { 3) There was little agreement between the faith } \\
\text { healers' classification and DSM-IIIR diagnosis. } \\
\text { 4) Faith healers use powerful techniques of } \\
\text { suggestion and cultural psychotherapeutic } \\
\text { procedures. }\end{array}$ \\
\hline
\end{tabular}


Table 1.

\begin{tabular}{|c|c|c|c|c|c|c|c|}
\hline Author & $\begin{array}{c}\text { Year of } \\
\text { publication }\end{array}$ & $\begin{array}{c}\text { Country of } \\
\text { study }\end{array}$ & Study design & $\begin{array}{c}\text { Sample } \\
\text { size }\end{array}$ & $\begin{array}{l}\text { Sample demographics } \\
\text { Gender: Age Method of } \\
\text { recruitment/sampling: }\end{array}$ & $\begin{array}{c}\text { Type of } \\
\text { instrument/ } \\
\text { method used }\end{array}$ & Title and findings \\
\hline Shah et al. & 2018 & Pakistan & $\begin{array}{c}\text { Some } \\
\text { quantitative } \\
\text { data followed } \\
\text { by } \\
\text { Cross sectional } \\
\text { in-depth semi- } \\
\text { structured } \\
\text { interviews }\end{array}$ & 50 & $\begin{array}{c}\text { Gender: } \\
26 \text { males } \\
24 \text { females } \\
\text { Age: Mean age } 36.2 \text { years } \\
\text { Method of recruitment: } \\
\text { Purposive sampling }\end{array}$ & $\begin{array}{l}\text { Perceived public } \\
\text { stigma scale } \\
\text { and an in-depth } \\
\text { semi-structured } \\
\text { interviews were } \\
\text { used }\end{array}$ & $\begin{array}{l}\text { "Impact of conventional beliefs and social stigma } \\
\text { on attitude towards access to mental health } \\
\text { services in Pakistan." } \\
\text { 1) The most significant finding on the Perceived } \\
\text { Public Stigma Scale related to carers believing } \\
\text { that people view receiving mental health } \\
\text { treatment as a sign of personal failure. } \\
\text { 2) Carers believed that people in the community } \\
\text { would treat someone who has received mental } \\
\text { health treatment just as they would treat } \\
\text { anyone. Someone who has received mental } \\
\text { health treatment is just as trustworthy as the } \\
\text { average person. People would accept someone } \\
\text { who has fully recovered from a mental illness as } \\
\text { a teacher of young children in a public school. } \\
\text { 3) In relation to patients, no socio-demographic } \\
\text { factor including age, gender, or marital status } \\
\text { or level of religious affiliation had a significant } \\
\text { effect on the intensity of conventional beliefs } \\
\text { towards mental health services (prior to or } \\
\text { after attending). Similarly, with carers, no socio- } \\
\text { demographic factors impacted on the intensity } \\
\text { of conventional beliefs or attitudes towards } \\
\text { their relative attending the mental health } \\
\text { service } \\
\text { 4) The majority (86\%) of patients having significant } \\
\text { symptoms of major mental illness had visited } \\
\text { traditional healers prior to engagement with the } \\
\text { mental health services. }\end{array}$ \\
\hline Sheikh et al. & 2000 & $\begin{array}{l}\text { Pakistan } \\
\text { and UK }\end{array}$ & $\begin{array}{l}\text { Cross sectional } \\
\text { questionnaire- } \\
\text { based survey }\end{array}$ & 287 & $\begin{array}{c}\text { Gender: } \\
\text { Pakistani } 30 \text { males, } 47 \\
\text { females } \\
\text { Age: } 18 \text { to } 60 \text { years } \\
2 \text { participants } 60 \text { years plus, } \\
\text { exact age of those two is } \\
\text { not given } \\
\text { Method of recruitment: } \\
\text { Convenience sampling by } \\
\text { approaching individuals on } \\
\text { two locations and suggesting } \\
\text { engagement }\end{array}$ & \begin{tabular}{|} 
Two questionnaires: \\
The orientations \\
to seeking \\
professional \\
help and the \\
mental distress \\
explanatory model \\
questionnaire \\
and in addition a \\
demographic data \\
sheet.
\end{tabular} & $\begin{array}{l}\text { "A cross cultural study of mental health beliefs and } \\
\text { attitudes towards seeking professional help." } \\
\text { 1) Positive attitudes toward seeking professional } \\
\text { help for psychological distress were similar for } \\
\text { British Asians, Westerners and Pakistanis. } \\
\text { 2) There were significant differences between } \\
\text { the three groups in the causal attributions of } \\
\text { mental distress. Culture, as a variable, was not } \\
\text { a significant predictor of a positive attitude to } \\
\text { seeking professional help. } \\
\text { 3) Causal beliefs of mental distress were } \\
\text { significant predictors of attitudes to seeking } \\
\text { help for the British Asian and the Pakistani } \\
\text { groups. } \\
\text { 4) Beliefs were not significant predictors for } \\
\text { seeking help for the Western group. } \\
\text { 5) Culturally determined causal beliefs of mental } \\
\text { distress contribute to attitudes towards seeking } \\
\text { professional help for psychological problems for } \\
\text { Asians. }\end{array}$ \\
\hline
\end{tabular}


Table 1.

\begin{tabular}{|c|c|c|c|c|c|c|c|}
\hline Author & $\begin{array}{c}\text { Year of } \\
\text { publication }\end{array}$ & $\begin{array}{l}\text { Country of } \\
\text { study }\end{array}$ & Study design & $\begin{array}{c}\text { Sample } \\
\text { size }\end{array}$ & $\begin{array}{l}\text { Sample demographics } \\
\text { Gender: Age Method of } \\
\text { recruitment/sampling: }\end{array}$ & $\begin{array}{c}\text { Type of } \\
\text { instrument/ } \\
\text { method used }\end{array}$ & Title and findings \\
\hline Suhail et al. & 2019 & Pakistan & $\begin{array}{c}\text { Vignette based } \\
\text { cross sectional } \\
\text { survey }\end{array}$ & 1750 & $\begin{array}{l}\text { Gender: } \\
850 \text { males } \\
900 \text { females } \\
\text { Age: range } 16 \text { to } 72 \text { years, } \\
\text { mean } 34.03 \text { years } \\
\text { Method of recruitment: The } \\
\text { sampling was quasi random. }\end{array}$ & $\begin{array}{l}\text { 1. Participants } \\
\text { were read } \\
\text { a vignette } \\
\text { describing } \\
\text { symptoms of } \\
\text { either psychosis } \\
\text { or major } \\
\text { depression. } \\
\text { 2. Participants } \\
\text { were requested } \\
\text { to provide } \\
\text { diagnosis, } \\
\text { causes, } \\
\text { prognosis, } \\
\text { and possible } \\
\text { treatments for } \\
\text { the disorders }\end{array}$ & $\begin{array}{l}\text { "A study investigating mental health literacy in } \\
\text { Pakistan." } \\
\text { 1) Depression was four times more likely to be } \\
\text { diagnosed than psychosis. } \\
\text { 2) The type of disorder, education status and area } \\
\text { of residence contributed significantly to one's } \\
\text { ability to diagnose. More people believed that } \\
\text { GPs, psychologists, and psychiatrists were the } \\
\text { right people to consult for these problems. } \\
\text { 3) Some participants considered Hakims and } \\
\text { Homeopaths, Magical and Religious Healers as } \\
\text { the appropriate people to contact. } \\
\text { 4) Those recognizing mental disorders were } \\
\text { more likely to identify the underlying causes, } \\
\text { prognosis and appropriate treatment of the } \\
\text { problems. }\end{array}$ \\
\hline $\begin{array}{c}\text { Tabassum } \\
\text { et al. }\end{array}$ & 2000 & UK & $\begin{array}{l}\text { Interview as } \\
\text { per interview } \\
\text { schedule }\end{array}$ & 74 & $\begin{array}{c}\text { Gender: } 22 \text { males } \\
29 \text { first generation females } \\
23 \text { second generation } \\
\text { females } \\
\text { Age: Median ages } 47.6,43.8 \\
\text { and } 19.7 \text { years, respectively } \\
\text { Method of recruitment: } \\
\text { Purposive sampling. }\end{array}$ & $\begin{array}{l}60 \text { to } 90 \text { minutes } \\
\text { long interviews } \\
\text { consisting of } \\
\text { a schedule } \\
\text { comprising of } 21 \\
\text { statements }\end{array}$ & $\begin{array}{l}\text { "Attitudes towards mental health in an urban } \\
\text { Pakistani community in the United Kingdom." } \\
\text { 1) There were differences in the models of } \\
\text { mental illness being employed with greater } \\
\text { somatisation of symptoms in the Pakistani } \\
\text { group and an emphasis on aggressive behaviour } \\
\text { as a significant symptom. } \\
\text { 2) Treatment expectations also varied with some } \\
\text { emphasis on traditional Pakistani treatments } \\
\text { such as Faith healers and Hakims as well as } \\
\text { General Practitioners and hospital treatments. } \\
\text { 3) Language difficulties, religious and cultural } \\
\text { practices were also identified as barriers to } \\
\text { female treatment in particular. }\end{array}$ \\
\hline Tareen et al. & 2008 & Pakistan & $\begin{array}{l}\text { Two staged } \\
\text { process: } \\
\text { Screening } \\
\text { through semi- } \\
\text { structured } \\
\text { questionnaire } \\
\text { followed by } \\
\text { consultation } \\
\text { by psychiatrist } \\
\text { of those that } \\
\text { were screened } \\
\text { positive }\end{array}$ & 98 & $\begin{array}{c}\text { Gender: } \\
50 \text { males } \\
41 \text { females } \\
\text { Age: } 10.93 \text { years (SD 5.29) } \\
\text { (male } 11.10 \text { vs. female 10.72) } \\
\text { Method of recruitment: } \\
\text { Purposive sampling }\end{array}$ & $\begin{array}{l}\text { 1. Questionnaire } \\
\text { administered to } \\
\text { a consecutive } \\
\text { series of young } \\
\text { persons and } \\
\text { their families } \\
\text { 2. Questionnaire } \\
\text { reviewed by } \\
\text { a psychiatrist } \\
\text { of a grade of } \\
\text { registrar who } \\
\text { made a clinical } \\
\text { diagnosis. }\end{array}$ & $\begin{array}{l}\text { "Primary care treatment for child and adolescent } \\
\text { neuropsychiatric conditions in remote rural Punjab, } \\
\text { Pakistan - a cross-sectional survey." } \\
\text { 1) Various frontline healthcare providers } \\
\text { included medically qualified practitioners, } \\
\text { Homeopathic doctors and Hakims (Greek } \\
\text { medicine, traditional herbal medicine), who had } \\
\text { prescribed mainly physical treatments such as } \\
\text { tablets, syrups, powders and pastes; } \\
\text { 2) Religious and faith healers relied mainly on } \\
\text { psychotherapeutic methods such as prayers } \\
\text { or giving amulets. In a small minority of cases, } \\
\text { physical beating was used as part of the } \\
\text { treatment process. } \\
\text { 3) The effectiveness of these treatments, as rated } \\
\text { by the patients and their families, was variable, } \\
\text { with highest reported effectiveness for general } \\
\text { practitioner treatments. }\end{array}$ \\
\hline
\end{tabular}


Table 1.

\begin{tabular}{|c|c|c|c|c|c|c|c|}
\hline Author & $\begin{array}{c}\text { Year of } \\
\text { publication }\end{array}$ & $\begin{array}{c}\text { Country of } \\
\text { study }\end{array}$ & Study design & $\begin{array}{l}\text { Sample } \\
\text { size }\end{array}$ & $\begin{array}{l}\text { Sample demographics } \\
\text { Gender: Age Method of } \\
\text { recruitment/sampling: }\end{array}$ & $\begin{array}{c}\text { Type of } \\
\text { instrument/ } \\
\text { method used }\end{array}$ & Title and findings \\
\hline Zafar et al. & 2009 & Pakistan & $\begin{array}{l}\text { A structured } \\
\text { questionnaire } \\
\text { was employed }\end{array}$ & 985 & $\begin{array}{c}\text { Gender: } \\
536 \text { males } \\
449 \text { females } \\
\text { Age: average } 36.7 \text { years } \\
\text { Method of recruitment: } \\
\text { Nonprobability convenience } \\
\text { sample of adults }\end{array}$ & $\begin{array}{l}\text { A cross-sectional } \\
\text { study. } \\
\text { A structured } \\
\text { questionnaire was } \\
\text { employed to survey } \\
\text { the knowledge } \\
\text { and perceptions } \\
\text { of adult general } \\
\text { public about } \\
\text { psychotherapy. }\end{array}$ & $\begin{array}{l}\text { "Psychotherapy for treatment modality for } \\
\text { psychiatric disorders: perceptions of general public } \\
\text { of Karachi Pakistan." } \\
\text { 1) It was noted that the majority claimed to be } \\
\text { aware of psychotherapy as a treatment option } \\
\text { for psychiatric disorders but } 47.5 \% \text { of these } \\
\text { failed to identify its correct definition. } \\
\text { 2) Concerns voiced by the participants about } \\
\text { psychotherapy included stigma and breech in } \\
\text { confidentiality; } 60.7 \% \text { opined it cost effective and } \\
86.5 \% \text { favoured its use as an adjuvant } \\
\text { modality. } \\
\text { 3) A preference for psychotherapy as the } \\
\text { treatment strategy for psychiatric disorders } \\
\text { was demonstrated by } 46.6 \% \text {. Younger, more } \\
\text { educated, financially independent and female } \\
\text { participants were more likely to prefer } \\
\text { psychotherapy as were those who deemed it } \\
\text { cost effective. } \\
\text { 4) Positive attitudes regarding the acceptability, } \\
\text { clinical utility and cost-effectiveness of } \\
\text { psychotherapy were observed in a sample } \\
\text { representative of general public of Karachi, } \\
\text { Pakistan. }\end{array}$ \\
\hline Zafar et al. & 2008 & Pakistan & $\begin{array}{l}\text { Cross section } \\
\text { survey, self- } \\
\text { administered } \\
\text { questionnaire }\end{array}$ & 404 & $\begin{array}{c}\text { Gender: } \\
77 \% \text { males } \\
33 \% \text { females } \\
\text { Age: Mean age } 31.4 \text { years } \\
\text { Method of recruitment: } \\
\text { Convenience sampling }\end{array}$ & $\begin{array}{l}\text { Data was } \\
\text { collected via a } \\
\text { self-administered } \\
\text { questionnaire. } \\
\text { Questions were } \\
\text { related to a } \\
\text { vignette of a young } \\
\text { man displaying } \\
\text { schizophrenic } \\
\text { behaviour }\end{array}$ & $\begin{array}{l}\text { "Perceptions about the cause of Schizophrenia and } \\
\text { subsequent help seeking behaviour in Pakistani } \\
\text { population-results of cross-sectional survey." } \\
\text { 1) Majority of participants were graduates } \\
\text { and employed. Only } 30 \% \text { of the participants } \\
\text { attributed 'mental illness' as the main cause } \\
\text { of psychotic symptoms while a large number } \\
\text { thought of 'God's will' (32.3\%), superstitious } \\
\text { ideas' (33.1\%), 'loneliness' (24.8\%) and } \\
\text { 'unemployment' (19.3\%) as the main cause. } \\
\text { 2) Mental illness as the single most important } \\
\text { cause was reported by only } 22 \% \text {. } \\
\text { 3) With regards to management, only } 40 \% \\
\text { reported psychiatric consultation to be the } \\
\text { single most important management step. } \\
\text { 4) Other responses regarding management } \\
\text { included spiritual healing (19.5\%) and Social } \\
\text { changes (10.6), while } 14.8 \% \text { of respondents said } \\
\text { that they would do nothing. } \\
\text { 5) Gender, age, family system and education level } \\
\text { were significantly associated with the beliefs } \\
\text { about the cause of schizophrenia. } \\
\text { 6) These variables plus 'religious inclination' } \\
\text { and 'beliefs about cause' were significantly } \\
\text { associated with the help seeking behaviour of } \\
\text { the participants. } \\
\text { 7) Despite majority of the study population } \\
\text { being well educated, only a few recognized } \\
\text { Schizophrenia as a mental illness and many } \\
\text { held superstitious beliefs. }\end{array}$ \\
\hline
\end{tabular}


Table 2: All studies judged against the following appraisal criteria for identification and appreciation of possible bias

\begin{tabular}{|c|c|c|c|c|c|c|c|c|c|c|c|c|c|c|c|c|c|c|c|}
\hline Are following satisfied & 1 & 2 & 3 & 4 & 5 & 6 & 7 & 8 & 9 & 10 & 11 & 12 & 13 & 14 & 15 & 16 & 17 & 18 & 19 \\
\hline $\begin{array}{l}\text { 1-Philosophical underpinnings clarified? } \\
\text { That is, epistemological and ontological perspective }\end{array}$ & $\mathrm{N}$ & D & N & $\mathrm{N}$ & L & D & $N$ & $\mathrm{~N}$ & $N$ & $N$ & $\mathrm{~L}$ & $\mathrm{~N}$ & $N$ & N & $N$ & $N$ & $\mathrm{~N}$ & $\mathrm{~N}$ & $\mathrm{~N}$ \\
\hline 2-Reasons provided for the choice of methodology and design? & $\mathrm{L}$ & D & L & L & D & D & $\mathrm{N}$ & $\mathrm{N}$ & N & $N$ & $\mathrm{D}$ & $L$ & $L$ & A & $L$ & $\mathrm{~L}$ & $\mathrm{~N}$ & $\mathrm{~N}$ & $\mathrm{~N}$ \\
\hline $\begin{array}{l}\text { 3-Credibility (Internal Validity) justified? } \\
\text { For example, having outside auditors or participants validate } \\
\text { findings (member checks), peer debriefing, attention to } \\
\text { negative cases, independent analysis of data by more than one } \\
\text { researcher, verbatim quotes, persistent observation }\end{array}$ & $\mathrm{N}$ & D & D & D & D & D & L & $\mathrm{L}$ & L & L & $\mathrm{D}$ & $L$ & $\mathrm{~L}$ & L & L & A & $\mathrm{L}$ & $\mathrm{L}$ & $\mathrm{L}$ \\
\hline $\begin{array}{l}\text { 4-Transferability (External validity or generalisability) } \\
\text { justified? } \\
\text { For example, providing details of the study participants to } \\
\text { enable readers to evaluate for which target groups the study } \\
\text { provides valuable information, providing contextual background } \\
\text { information, demographics, the provision of thick description } \\
\text { about both the sending and the receiving context and so on }\end{array}$ & L & D & D & A & A & D & $\mathrm{L}$ & $L$ & L & $L$ & D & $L$ & L & $\mathrm{L}$ & L & L & $\mathrm{L}$ & $L$ & $\mathrm{~L}$ \\
\hline $\begin{array}{l}\text { 5-Dependability (Reliability or consistency) justified? } \\
\text { Peer review, debriefing, audit trails, triangulation in the context } \\
\text { of the use of different methodological approaches to look at the } \\
\text { topic of research, reflexivity to keep a self-critical account of the } \\
\text { research process, calculation of inter-rater agreements }\end{array}$ & $\mathrm{N}$ & D & D & A & A & $D$ & $\mathrm{~N}$ & $L$ & L & $N$ & $D$ & $L$ & $L$ & $\mathrm{~L}$ & $L$ & $L$ & $\mathrm{~L}$ & $L$ & $\mathrm{~L}$ \\
\hline $\begin{array}{l}\text { 6-Confirmability (Objectivity or neutrality) justified? } \\
\text { Assessing the effects of the researcher during all the steps } \\
\text { of the research process, reflexivity, providing background } \\
\text { information on the researcher's background, education, } \\
\text { perspective, school of thought }\end{array}$ & L & $D$ & D & D & L & $D$ & $\mathrm{~L}$ & $L$ & L & $N$ & $D$ & $A$ & $L$ & $D$ & L & $N$ & $\mathrm{~N}$ & $\mathrm{~N}$ & $\mathrm{~N}$ \\
\hline
\end{tabular}

$\mathrm{N}=$ None, $\mathrm{L}=$ Little, $\mathrm{A}=$ Adequate, $\mathrm{D}=$ Detailed

(Manual critical analysis by author)

None $=$ No information provided at all

Little $=$ Little information is provided though very superficial

Adequate $=$ Some discussion offered related to overall aim of the study

Detailed $=$ Detailed description is offered

that they offer to the participants that might be causing mental illness, such as 'Saya,' 'Jinn possession' and 'Churail' are separate entities that faith healers may offer solutions for to individual participants.

Multiple studies highlight the importance of religion when it comes to understanding or addressing the mental health problems. Religion appears to be playing a vital role in the understanding of the Pakistani population with regards to their mental health problems. For example, Cinnirella et al. (1999) reported that religious affiliation intertwines with ethnic origin or result in some important differences in the beliefs prevalent in Pakistani community living in Britain. Croot et al. (2008) attempted to find the reasons participants (parents and grandparents) ascribe to the learning disability of their children/grandchildren and found that participants felt that there could be theological reasons for the disability of their children, including disabilities being 'gift from God', 'test from God', 'chosen parents', 'punishment' and 'curse'.

Participants in a few studies identified psychological reasons responsible for their mental health problem, though the 
proportion of such participants in the included studies were remarkably low. For example, Naeem et al. (2007) discovered that participants believed that mental health problems were the result of stress or trauma. Again, with a minority group, Choudhry et al. $(2013,2018)$ reported that participants identified that psychological disturbances emanate from lack of sharing caused mental illness, further elaborating that the rich don't share with poor and with self-downing, that is, what can we do, it's all circumstantial. Imran et al. (2015) found in the younger aged participants that adolescents' own emotional state, stress, family problems and bad luck were endorsed by the participants as some of the causal factors in their mental illness. Sadia et al. (2017) report that stress, family problems, lack of friends and financial worries were endorsed strongly by the participants as the cause of their mental illness.

Gunasinghe (2018) reported that their research interviews illustrated tensions that the participants experienced when considering 'izzat' (a culture specific concept), that is, how issues related to izzat are negotiated to enable them to selfmanage or seek help, and possible life experiences that might lead to self-harm and attempted suicide. These culture specific concepts also point towards the psychological causation of mental health problems.

\section{Understanding of protective factors against mental illness as perceived by the Pakistani community}

Religion, faith and cultural customs have been reported by the participants as protective factors against mental illnesses. For example, Cinnirella et al. (1999) found that in terms of religion, it emerged that the Pakistani participants felt that religion did have a positive impact on their choice of strategies for dealing with depression. Choudhry et al. (2018), on their study on Kalasha ethnic minority community, found that psychological resilience and cultural protective factors were identified by the participants as buffers against mental health problems including intra-communal bonding and sharing; Kalasha festivals and traditions; purity concept; behavioural practice of happiness and cognitive patterns unique to Kalasha community.

\section{Treatment options of mental illness perceived by the Pakistani community}

If we combine the relevant information regarding the treatment options, the most common types of practitioners preferred by the Pakistani community are quite succinctly summarised in the study conducted by Mirza et al. (2006), who found that five different types of health care providers are offering their services including general practitioner (GP), Religious Healer
(Maulvi, Peer, Fakir), Hakim (a form of Unani/Greek medicine practitioner), Homeopathic doctors and Faith Healers (Amil, Sinyasi). They found that all these five main types of primary mental health care providers were using a range of physical, spiritual and psychotherapeutic treatments. Shah et al. (2018) reported that the majority (86\%) of patients having significant symptoms of major mental illness visited a traditional healer prior to their engagement with the mental health services.

In a separate study, Tareen et al. (2008) found that participants in their study consulted medically qualified practitioners, Homeopathic doctors and Hakims, who mainly prescribed physical treatments such as tablets, syrups, powders and pastes; and religious and faith healers, who relied mainly on psychotherapeutic methods such as prayers or giving amulets.

Worryingly, in a small minority of cases, physical beating was used as a part of the treatment process in the above mentioned study.

Saeed et al. (2000) noted that the classification used by faith healers is based on the mystic cause of disorders: saya, jinn possession or churail. In their study, they interviewed participants following their interactions with faith healers and found that sixty one percent of attenders were given a research diagnosis of mental disorder. They also noticed in their study that there was little agreement between the faith healers' classification and DSM-IIIR diagnosis.

For expatriate Pakistanis, the choice to seek help from not medically qualified traditional practitioner in the community was also found by Rashda et al. (2000), who reported that in Pakistani community living in the UK, treatment expectations varied with some emphasis on traditional Pakistani treatments such as Faith Healers and Hakims, as well as general practitioners and hospital treatments. The researchers found that language difficulties, religious practices and cultural practices were also identified as barriers in treatment of mental illnesses especially in case of female patients.

Naeem et al. (2007) reported that the participants believed that mental health problems were the result of stress or trauma, and that only medicines could help them. Zafar et al. (2008) found that only $22 \%$ of the participants reported mental illness as the single most important cause of their mental health problems. When they talked about management with same set of participants, only $40 \%$ reported psychiatric consultation to be a considerable management step. Other responses included spiritual healing and social changes, whilst $14.8 \%$ of respondents said that they would do nothing. 
Pakistani communities don't dismiss the possibility of treatment by mental health professionals altogether, for example, Suhail et al. (2019) reported that in their study population, more people believed that general practitioner's (23.76\%), psychologists (23.92\%) and psychiatrists (20.73\%) were the right people to consult for these problems. Compared to the above, there were also a lesser proportion who considered Hakims/Homeopathy Practitioners (4.22\%), Magical Healers (13.11\%) and Religious Healers (13.54\%) as the appropriate people to contact, but their percentage was less as compared to those who preferred medical and mental health professionals.

Findings of choosing the non-medical means of treatment were also replicated in the studies conducted with ethnic minority groups as well; Choudhry et al. (2018) found that participants from Kalasha community identified a variety of preferred interventions including shamanic treatment; ta'awiz (amulets); communal sharing and problem solving; medical treatment and herbal methods for management of their mental difficulties or problems.

With regards to treatment seeking behaviour in the expatriate Pakistanis, Cinnirella (1999) reported that the Muslim Pakistani participants in their study indicated a fear of community stigma associated with mental illness or, more worryingly, even the act of seeking help, which according to authors must surely have an impact on the actual coping strategies and help-seeking behaviours. In terms of helpseeking behaviours, their study has also highlighted a tendency for the members of Pakistani community to prefer consultations with professionals of the same background. Here, fear of being misunderstood due to ignorance of cultural and religious practices, intertwines in a complex fashion with the fear of being the target of racism, and a general feeling that it is easier to talk to professionals with whom one shares a common group identity. Sheikh et al. (2000) carried out their study in the UK and reported that positive attitudes toward seeking professional help for psychological distress were similar for British Asians, Westerners and Pakistanis. However, they found significant differences between the three groups in the causal attributions of mental distress.

James et al. (2002) studied the acceptance of an integrated mental health service at a three month's follow up period and reported that individuals' use of integrated mental health and other care was modest. Perceptions improved over three months.

Description of some culturally specific terms used in results section is as follows:
Hakims are a kind of health care professionals in Pakistan that deal with non-allopathic medications; they claim to be using Greek (locally called Unani) medications.

Saya literally means shadow; it's a culturally driven concept that means that an evil shadow can affect a person.

Churail is used in the same meanings as witchcraft.

Jinn literally means ghost.

Izzat literally means honour and the term is used in multiple meanings in Pakistani culture, for example, honour killings are the murders in name of Izzat, that are well known in this culture.

Maulvi is the religious scholar.

Peer is the Faith Healer.

Faqeer is a spiritually uplifted and wise person who abstains from worldly pleasures.

Amil is a person who knows certain magical methods and words to negatively influence others.

Sanyasi is a person who abstains from worldly pleasures and avoids communications with other humans, keeping self away in a lonely/distant place.

Shamanic treatment is a kind of spiritual treatment aimed at reaching deep levels of ancestral memory.

\section{DISCUSSION}

Understanding humanity in general and various peoples and cultures of the world systematically in particular falls under the remit of Anthropology (Peoples et al., 2011). Cultural anthropology is a subbranch of Anthropology (Peoples et al., 2011). A lot of work has also been done in understanding the sociology of mental health (Aneshensel et al., 1999). The debate whether mental illness has universal biological grounds or is the product and outcome of cultural factors resulting in the development of a reaction began long time ago (Aneshensel et al., 1999). Thomas Szasz (Szasz,1962), for example, advocated that mental illness is nothing but a myth that is used to label socially devalued behaviour. Laing (Laing, 1973) was of the opinion that mental illness is a sane response of individuals to an insane society that helps a person disassociating himself from intolerable circumstances. At the same time, the Diagnostic 
and Statistical manual of the mental health diseases (DSM-IV) is based on the premise of the universality of the mental health problems that have the same foundations across cultures though their presentation may vary according to individual society. Diagnostic and statistical manual of mental disorders ((DSMIV) (American Psychiatric Association, 1994, pp. xxi-xxii)) defines mental illness as unique patterns and behaviours that result from personal dysfunction of an individual and manifest as functional impairment and distress. This definition of DSM differentiates mental illness from any expected responses from society that may generate such behavioural patterns or from any deviant behaviours themselves. The debate that how culture affects the mental illness or whether it is responsible for mental illness is neither new nor recent. Each perspective is backed by a huge amount of empirical and theoretical research findings that supports its respective explanation of development of mental illness (Aneshensel et al., 1999).

The knowledge synthesized in this systematic review highlights both aspects about the understanding of Pakistani community regarding their mental health. For example, if we compare the tendency to somatisation and avoidance of acceptance of psychological and emotional difficulties, then a similar pattern is seen in the Chinese population where 'Neurasthenia' is very commonly observed as a substitute for Depression (Cheun, 1981; Kleinman, 1977, Marsella, 1973; Tseng, 1975). Likewise some work has been carried out on The Hutterite community that is Anabaptist sect of Christianity that originated in Europe in the sixteenth century but later emigrated to USA and Canada to avoid religious persecution in $19^{\text {th }}$ and $20^{\text {th }}$ century where they have settled as religious communes ever since (McLaren, 1999). In 1950s, psychiatrist Joseph Weil and sociologist Joseph Eaton carried out a research on the Hutterite community that was funded by National Institute of Mental Health Research $(\mathrm{NIMH})$ as they felt that this group is socially and genetically homogenous group and will provide insight into sociocultural factors impacting mental health (Eaton, 1955). The findings suggested that this community showed high levels of psychotic illness (Eaton, 1955). Eaton concluded that 'the Hutterite way of life, despite the good mental health reputation of its members, provides no immunity from severe psychiatric disorders' ( $p$. 53) (Eaton, 1955). Findings of this study supports the biological explanation of illness development. Whilst working on Pakistani and Bangladeshi communities in the United Kingdom, Penny et al. (2009) found unique sociocultural practices carried out to achieve treatment of mental health problems, for example, whispering (sacred verses) on water as means of a spiritual treatment of mental illness (Penny, 2009). Finally, if we compare the understanding and practices of Pakistani community with neighbouring India that is rich in cultural diversity, that again supports the importance of culture in influencing the presentation on mental health whilst accepting the biological predispositions at the same time (Gautam, 2010).

The aim of this systematic review was to attempt to summarize and understand the overall literature available in our subject of interest. The information is required for several reasons. Currently, some patchy and superficial knowledge is available about the understandings of Pakistani community in the above described areas, but there is a gap in literature where any attempts are ever made in the past to systematically review the knowledge and learn lessons from the overall process and findings. This is where I envisage that findings from this review be integrated in the overall body of literature presently available. I hope that possible implications on current psychiatric practice would include improvement in the quality of services that patients may become informed by this information, in depth understanding of the subjective experience of patient, help in services development and overall information availability in this area for planning at the level of higher management.

Social constructionism is a theory of knowledge that deals with the jointly constructed understandings of the world that make foundations of shared assumptions about reality (Hacking et al., 1999). Social constructionism and symbolic interactionism are helpful whilst attempting to learn that how social scientists in each community try to understand mental experiences or mental health problems of the members of community. There is no such scientific work carried out so far that uses these methodologies in Pakistan. Phenomenological approaches are used in the studies conducted outside Pakistan but hardly any are conducted inside the country.

The studies seem to suggest that Pakistani people have little (sometimes negligible) understanding of their mental health needs or mental illnesses. There are cultural factors that strongly play a role towards their understanding of the mental illness including the possibility of non-medical causes. Multiple cultural factors play a role towards the development of these perceptions and explanatory models, out of which religion, faith and spirituality related themes tend to emerge as repetitive factors that mental illness is ascribed to. Some cultural constructs, for example, the construct of 'Izzat' plays an important role towards help seeking behaviour. Stigma attached with mental illness is a repetitive finding and appears to be affecting both genders, but female gender has been reported to be more affected than males. The treatment choices are affected by the explanatory model of the illness and as some people tend to prefer medical practitioners or psychiatrists to receive treatment, others prefer other kind of non-licenced 
practitioners including Spiritual/Faith Healers, Hakims and so on.

It appears that these findings are in such a broad spectrum that in order to address them, a combined effort is required at many levels and from professionals of multiple disciplines. Addressing the culture, educating those involved in care, training more number and better quality of mental health professionals and emphasizing the importance of increasing awareness about mental processes, mental health and mental health related issues are all required and that needs a combined effort from the Government and the citizens alike to achieve these goals.

In one of the bigger cities, some people, especially those who are relatively more educated and of younger age group, consider psychotherapy as an acceptable option; whilst in the same city, a big proportion of research population had rather limited or no knowledge of what psychotherapy is and did not consider it as an acceptable treatment option.

This study is the first step of its kind that is highlighting the importance that we as a nation have above understandings about our mental health and related issues and we carry out and engage in identified practices as a community that are sometimes useful but mostly harmful and sometimes even dangerous. It is hoped that this effort will encourage others for further exploration of experiences and practices that I have identified superficially in this project, but that requires a more continued in-depth exploration as multiple qualitative mental health research projects, whether at a smaller level or bigger. I take the opportunity to encourage other researchers to engage in similar kind of research efforts like this one and find ways to introduce their own innovations where appropriate.

\section{CONCLUSION}

Overall, the results suggest that Pakistani community has unique perceptions regarding their mental health and related problems. The unique understandings about the causation, impact, protective factors and treatment options are all driven by a variety of socio-cultural-religious factors that are manifested in individual and group practices. Such cultural understandings and practices need to be incorporated to develop a complete picture that how Pakistani community understands their mental health and related issues and how this community can be best helped when it comes to addressing the mental health difficulties and problems.

Mental health and mental health research services are underdeveloped in Pakistan. Studies show that awareness around mental health or mental illness is limited to nonexisting. With regards research in this field, it's again at a very preliminary level and there is room for further research, specifically high quality qualitative psychiatric research including those incorporating ethnographic methods that are essentially required to understand the social construction regarding the perceptions of mental health and mental illness in the Pakistani community.

\section{LIMITATIONS}

The following points are important to note:

1. As described in the introduction section, Pakistan is divided in four parts based on ethnic backgrounds. The studies identified in this systematic review have been conducted mainly in Punjab province and Karachi, which is a metropolitan city. Three other major parts including Khyber Pakhtunkhwa (formerly called NWFP), Sindh and Baluchistan have no representative studies in the review, hence a generalisation is beyond realistic.

2. Only a few studies throw light on the mental health of ethnic minorities. These studies (two in total) attempted to focus on nomads and Kalasha communities that collectively constitute less than $1 \%$ of the total population. The nomads are a constantly mobile group and don't consider themselves belonging to any ethno-regional group. The bigger ethno-religious minority groups, for example, the Pakistani Christians or Pakistani Hindus have no representation at all in the currently available studies.

3. No study discusses mental health of children or old aged people, though one study focuses on findings in the adolescent population; nevertheless, this was not separately conducted but the findings of a larger study was divided into two parts.

4. 12 out of 19 studies were conducted in Pakistan. 5 studies were conducted on the Pakistani population in the UK. One study was done in Pakistan and the UK at the same time. One study was carried out in Pakistan and India.

5. 7 out of 12 studies conducted in Pakistan were questionnaire-based studies. The study conducted in Pakistan and UK was also questionnaire based. Hence, 13 out of 19 studies were questionnaire-based studies where quantitative data was collected by various methods. Out of the remaining 5 studies that were conducted in Pakistan, one was a focused group study, two were in-depth interview studies, one was semi-structured interview-based study and one was vignette based cross sectional survey. Hence, there were two studies conducted in Pakistan that were 
based on in-depth interviews; out of this, there was only one study that took an ethnography-informed approach. Nevertheless, the authors of the study described that it was not a true ethnography study as no observation of participants was carried out in any way. This leads to the conclusion that there was a general lack of qualitative psychiatric research in Pakistan and no ethnographybased work has been done so far in this area. Although qualitative health research studies don't test a hypothesis and are instead conducted to produce a hypothesis or to open avenues for further research, yet there is a general sacristy of studies that makes any generalisations far from realistically possible.

6. Most of the studies fall low on general critical appraisal criteria and some obvious questions arise about their internal and external validity.

7. Most of the studies outside Pakistan have been conducted in the United Kingdom. Four out of five studies have used interviews (in depth, semi-structured, per-schedule) as methodology. One used focused group with participants from three different ethnic/cultural backgrounds. On the one hand, these studies highlight the importance of some important cultural concepts for example that of 'izzat' that this expatriate population has imported to the host society from parent culture. However, when it comes to interpretation of findings, the importance of this essential confounder cannot be ignored that most of the participants were living outside Pakistan for variable time period, for example, one study included second and third generation participants. Also, the acknowledgement of the possible other factors, for example, how the local cultural and environmental factors may influence the expression of participants needs to be done.

8. Cross sectional questionnaire-based studies, especially those with a large number of participants, impart value towards understanding of a larger mindset prevailing in an area. Nevertheless, certain facts about such studies need to be acknowledged including their cross-sectional time frame and limited choices available to participants as provided by the framework offered by researchers. None of the studies offered any details about the validity or reliability of the research tools used.

\section{ACKNOWLEDGEMENT}

Special thanks to Prof Reinhard Heun for supporting me throughout the process of this research work by providing prompt expert advice at every step from the beginning of the project till the end. Global Psychiatry Platform is a source of motivation for researchers like me, where I received technical help and an international publication platform for my research work.

Thanks to Dr Muhammad Arshad of Independent Medical College, Marzi Pura, Faisalabad, Pakistan for support at various stages of research process.

Thanks to Maryam, Sachal and Zeest of Dehliz-e-Zeest for providing moral support throughout the research process.

\section{DECLARATIONS}

\section{Conflict of interest}

We do not identify any conflict of interest in this project.

\section{Ethical approval}

The research process did not involve any direct engagement with clients; hence, it didn't require a formal ethical approval.

\section{Informed consent}

As mentioned above, informed consent was not required.

\section{Funding}

No financial support of any sort was sought throughout this research project. 


\section{REFERENCES}

Aisha Ikram, MPhil,1 Kausar Suhail, PhD, 1 Sadaf Zara Jafery, MPhil, 1 and Swaran Singh, MD, FRCPsych2 Isr J Psychiatry Relat Sci - Vol. 48 - No. 2 (2011), Rates of Expressed Emotions in Pakistani Relatives of Patients with Schizophrenia.

American Psychiatric Association, 2013. Diagnostic and statistical manual of mental disorders. BMC Med, 17, pp. 133-137.

Aneshensel, C.S. and Phelan, J.C. eds., 1999. Handbook of the sociology of mental health (pp. 3-18). New York: Kluwer Academic/ Plenum Publishers.

Bhugra, D. and McKenzie, K., 2003. Expressed emotion across cultures. Advances in Psychiatric Treatment, 9(5), pp. 342-348.

Brown, G.W., Birley, J.L. and Wing, J.K., 1972. Influence of family life on the course of schizophrenic disorders: A replication. The British Journal of Psychiatry, 121(562), pp. 241-258.

Cinnirella, M. and Loewenthal, K.M., 1999. Religious and ethnic group influences on beliefs about mental illness: A qualitative interview study. British Journal of Medical Psychology, 72(4), pp. 505-524.

Cheung, F.M., Lau, B.W. and Waldmann, E., 1981. Somatization among Chinese depressives in general practice. The International Journal of Psychiatry in Medicine, 10(4), pp. 361-374.

Choudhry, F.R. and Bokharey, I.Z., 2013. Perception of mental health in Pakistani nomads: An interpretative phenomenological analyses. International journal of qualitative studies on health and well-being, 8(1), p. 22469.

Choudhry, F.R., Khan, T.M., Park, M.S.A. and Golden, K.J., 2018. Mental Health Conceptualization and Resilience Factors in the Kalasha Youth: An Indigenous Ethnic and Religious Minority Community in Pakistan. Frontiers in public health, 6.

Cochrane, R. and Sashidharan, S.P., 1996. Mental health and ethnic minorities: a review of the literature and implications for services. Ethnicity and Health. York: Centre for Reviews and Dissemination, University of York, pp. 105-26.

Croot, Croot, E.J., Grant, G., Cooper, C.L. and Mathers, N., 2008. Perceptions of the causes of childhood disability among Pakistani families living in the UK. Health \& Social Care in the Community, 16(6), pp. 606-613.
Diagnostic, A., 1994. statistical manual of mental disorders. American Psychiatric Association. Washington, DC, p. 886.

Eaton, J.W. and Weil, R.J., 1955. Culture and mental disorders.

Gunasinghe, C., Hatch, S.L. and Lawrence, J., 2019. Young Muslim Pakistani Women's Lived Experiences of Izzat, Mental Health, and Well-Being. Qualitative health research, 29(5), pp. 747-757.

Gautam, S. and Jain, N., 2010. Indian culture and psychiatry. Indian journal of psychiatry, 52(Suppl1), p. S309.

Gaw, A., 1993. Culture, ethnicity, and mental illness. American Psychiatric Pub. Brown,

Gilbert, P., Gilbert, J. and Sanghera, J., 2004. A focus group exploration of the impact of izzat, shame, subordination and entrapment on mental health and service use in South Asian women living in Derby. Mental Health, Religion \& Culture, 7(2), pp. 109-130.

Gopalkrishnan, N., 2018. Cultural diversity and mental health: Considerations for policy and practice. Frontiers in public health, 6 .

Hacking, lan, and Jan Hacking. The social construction of what? Harvard university press, 1999.

Hussain, S., Imran, N., Hotiana, U.A., Mazhar, N. and Asif, A., 2017. Illness perceptions in patients of schizophrenia: A preliminary investigation from Lahore, Pakistan. Pakistan journal of medical sciences, 33(4), p. 829.

Higgins, J. P. T., \& Green, S. (2017). Cochrane Handbook for Systematic Reviews of Interventions, Version 5.1. 0. London: The Cochrane Collaboration; 2011.

Hostetler, J.A., 1997. Hutterite society. JHU Press.

Imran, N., Azeem, M.W., Chaudhry, M.R. and Butt, Z., 2015. Illness perceptions in adolescents with a psychiatric diagnosis in Pakistan. BJPsych bulletin, 39(4), pp. 174-178.

James, S., Chisholm, D., Murthy, R.S., Kumar, K.K., Sekar, K., Saeed, K. and Mubbashar, M., 2002. Demand for, access to and use of community mental health care: lessons from a demonstration project in India and Pakistan. International Journal of Social Psychiatry, 48(3), pp. 163-176. 
Kleinman, A., 1982. Neurasthenia and depression: a study of somatization and culture in China. Culture, medicine and psychiatry, 6(2), pp. 117-190.

Laing, R.D., 1973. The Politics of Experience (New York: Ballantine, 1967). Freud, A. Normality and Pathology in Childhood. New York: International Univer-Group for The Advancement of Psychiatry. Normal Adolescence: Its Dynamics Eisen, P. The generation gap. World Medicall, 3, p. 47.

Loya, F., Reddy, R. and Hinshaw, S.P., 2010. Mental illness stigma as a mediator of differences in Caucasian and South Asian college students' attitudes toward psychological counselling. Journal of Counselling Psychology, 57(4), p. 484.

Mannheim, K., 1936. Ideology and Utopia New York. Merton, Robert (1957) Social Theory and Social Structure, New York.

Marsella, A.J., Kinzie, D. and Gordon, P., 1973. Ethnic variations in the expression of depression. Journal of Cross-Cultural Psychology, 4(4), pp. 435-458.

McCabe, R. and Priebe, S., 2004. Explanatory models of illness in schizophrenia: comparison of four ethnic groups. The British Journal of Psychiatry, 185(1), pp. 25-30.

Mirza, I., Mujtaba, M., Chaudhry, H. and Jenkins, R., 2006. Primary mental health care in rural Punjab, Pakistan: Providers, and user perspectives of the effectiveness of treatments. Social Science \& Medicine, 63(3), pp. 593-597.

Naeem, F., Ayub, M., Kingdon, D. and Gobbi, M., 2012. Views of depressed patients in Pakistan concerning their illness, its causes, and treatments. Qualitative Health Research, 22(8), pp. 1083-1093.

Newcomb, L., 1986. The Islamic Republic of Pakistan: country profile. International demographics, 5(7), pp. 1-8.

Pattanayak, D.P. ed., 1990. Multilingualism in India (No. 61). Multilingual Matters.

Peacock, J.L., 1981. Durkheim and the social anthropology of culture. Social Forces, 59(4), pp. 996-1008.

Penny, E., Newton, E. and Larkin, M., 2009. Whispering on the water: British Pakistani families' experiences of support from an early intervention service for first-episode psychosis. Journal of cross-cultural psychology, 40(6), pp. 969-987.
Peoples, J. and Bailey, G., 2011. Humanity: An introduction to cultural anthropology. Cengage Learning.

Saeed, K., Gater, R., Hussain, A. and Mubbashar, M., 2000. The prevalence, classification and treatment of mental disorders among attenders of native faith healers in rural Pakistan. Social psychiatry and psychiatric epidemiology, 35(10), pp. 480-485.

Shah, I., Khalily, M.T., Ahmad, I. and Hallahan, B., 2019. Impact of Conventional Beliefs and Social Stigma on Attitude Towards Access to Mental Health Services in Pakistan. Community mental health journal, 55(3), pp. 527-533.

Sheikh, S. and Furnham, A., 2000. A cross-cultural study of mental health beliefs and attitudes towards seeking professional help. Social psychiatry and psychiatric epidemiology, 35(7), pp. 326-334.

Squires, V.R. ed., 2011. The Role of Food, Agriculture, Forestry and Fisheries in Human Nutrition-Volume III. EOLSS Publications.

Suhail, K., 2005. A study investigating mental health literacy in Pakistan. Journal of mental health, 14(2), pp. 167-181.

Szasz, T.S., 1992. The myth of mental illness. American Psychological Association.

Tabassum, R., Macaskill, A. and Ahmad, I., 2000. Attitudes towards mental health in an urban Pakistani community in the United Kingdom. International Journal of Social Psychiatry, 46(3), pp. 170-181.

Tareen, A., Mirza, I., Mujtaba, M., Chaudhry, H.R. and Jenkins, R., 2008. Primary care treatment for child and adolescent neuropsychiatric conditions in remote rural Punjab, Pakistan-a cross-sectional survey. Child: care, health and development, 34(6), pp. 801-805.

Tseng, W.S., 1975. The nature of somatic complaints among psychiatric patients: the Chinese case. Comprehensive psychiatry.

World Health Organization, 1992. The ICD-10 classification of mental and behavioural disorders: clinical descriptions and diagnostic guidelines. Geneva: World Health Organization.

Zafar, A.M., Jawaid, A., Ashraf, H., Fatima, A., Anjum, R. and Qureshi, S.U., 2009. Psychotherapy as a treatment modality for psychiatric disorders: Perceptions of general public of Karachi, Pakistan. BMC psychiatry, 9(1), p. 37. 
Zafar, S.N., Syed, R., Tehseen, S., Gowani, S.A., Waqar, S., Zubair, A., Yousaf, W., Zubairi, A.J. and Naqvi, H., 2008. Perceptions about the cause of schizophrenia and the subsequent help seeking behavior in a Pakistani population-results of a cross-sectional survey. BMC psychiatry, 8(1), p. 56.

Zerubavel, E., 2009. Social mindscapes: An invitation to cognitive sociology. Harvard University Press. 